\title{
Anti-oxidative, acetylcholinesterase and pancreatic lipase inhibitory activities of compounds from Dasiphora fruticosa, Myricaria alopecuroides and Sedum hybridum
}

\author{
G.Odontuya \\ Institute of Chemistry and Chemical Technology, Mongolian Academy of Sciences, \\ Peace Avenue, Ulaanbaatar 13330, Mongolia
}

ARTICLE INFO: Received: 25 Oct, 2016; Revised: 15 Dec, 2016; Accepted: 22 Dec, 2016

\begin{abstract}
Total of 35 phenolics and flavonols were isolated from flowers and leaves of Dasiphora fruticosa Rydb., from branches of Myricaria alopecuroides Schrenk. and from the herb of Sedum hybridum L. The isolated compounds were identified on the basis of spectral data and tested for their anti-oxidative, acetylcholinesterase and pancreatic lipase inhibitory activities.Quercetin glycosides, gallic acid, (-)EGCG and gossypetin-8-O-xylopyranoside tellimagrandin II exhibited strong anti-oxidative activity by the DPPH scavenging method. The acetylcholinesterase inhibitory activity of quercetin glycosides and (-)EGCG was higher than those of other compounds. Whereas, tellimagrandin II, (-)EGCG and gallic acid derivatives exhibited the most potent inhibitory activity against the pancreatic lipase enzyme among the isolated compounds. Only (-)EGCG showed a prominent activity against all assayed experiments. It was concluded that these plants could be studied further for their potential as anti-oxidative, anti-aging and lipid lowering active products.
\end{abstract}

Keywords: Flavonol, gallic acid, tellimagrandin II, antioxidant, anti-aging, lipid lowering activity

Copyright $\odot 2016$ Odontuya G. This is an open access article distributed under the Creative Commons Attribution 4.0 International License CC BY, which permits unrestricted use, distribution, and reproduction in any medium, provided the original work is properly cited.

\section{INTRODUCTION}

Traditionally, flowers, leaves and scions of Dasiphora fruticosa Rydb. (Rosaceae) were used to cure diarrhea, dysentery and other digestive organs disorders, as well as for relieving the neurological disorders [1, 2]. Scions and branch of Myricaria alopecuroides Schrenk. (Tamaricaceae) have generally been used to neutralize the incidents of poisoning from different kinds of origins, to alleviate the diffused and concealed chronic fever and to treat several of diseases including rash, boils, chronic ulcers, phthisis, spasms and atrophy [1,3,4]. The herb of Sedum hybridum L. (Crassulaceae) has been used for the treatment of diarrhea, dysentery, sepsis, thyroid, blood vessel disease and seizures related with nervous system $[1,4,5]$.

Previous studies revealed the presence of quercetin derivatives in the leaves of $D$.fruticosa [6, 7], gallic acid and its esterified derivatives in M.alopecuroides [8,9] and some flavonols and coumarins in S.hybridum [10].

The anti-oxidative, antibacterial activities of crude extracts, fractions and some compounds from the investigated plant samples have been partly reported [11-13]. As a part of continuing work on these plants, we report herein the content of bio-active compounds in the crude drugs, the characteristic phytochemicals and their anti-oxidative, acetylcholinesterase, and pancreatic lipase inhibitory activities.

*corresponding author: e-mail: g.odontuya@hotmail.com DOI: http://dx.doi.org/10.5564/mjc.v17i43.746

\section{EXPERIMENTAL}

General experimental procedures: Thin layer chromato chromatography (TLC) was performed on pre-coated silica gel $60 \mathrm{~F}_{254}$ plate (Merck, Darmstadt, Germany) and the spots were detected under UV radiation $(366 \mathrm{~nm})$ by spraying with $1 \%$ methanolic diphenylboric acid- $\beta$ ethylamino ester (NP), $5 \%$ ethanolic polyethylene glycol (PEG). For column chromatography (CC) Sephadex LH-20 (25-100 mm, Pharmacia, Uppsala, Sweden), $\mathrm{MCl}$ gel - CHP-20P (75-150 $\mu \mathrm{m}$, Mitsubishi Chemical Corporation, Japan), Sepra ${ }^{\mathrm{TM}}$ C18-E $\left(50 \mu \mathrm{m}, 65 \mathrm{~A}^{\circ}\right)$, Silica gel 60 (40-60 $\mu \mathrm{m}$, Merck, Darmstadt, Germany) were used. UV spectroscopic analysis was carried out on spectrophotometer UV-160 (Shimadzu, Japan) using 5\% $\mathrm{AlCl}_{3}, 1 \mathrm{~N} \mathrm{HCl}, \mathrm{CH}_{3} \mathrm{COONa}$ and $\mathrm{H}_{3} \mathrm{BO}_{3}$ diagnostic reagents. All used reagents and solvents were with analytical grade. ${ }^{1} \mathrm{H}(500 \mathrm{MHz})$ and ${ }^{13} \mathrm{C}$ NMR $(125 \mathrm{MHz})$ spectra were recorded on Bruker AMX-500, respectively. Quantitative analysis was carried out on spectrophotometer UV-2550 (Shimadzu, Japan).

Plant materials: All investigated plant samples were prepared from the Gobi-Altai aimag. Especially, flowers and leaves of Dasiphora fruticosa were collected from the mountain Khasagt Khairkhan, in June-July, 2004, flowered green branches of Myricaria alopecuroides from the riverside meadow, in late July, 2007 and aerial parts of Sedum hybridum from the ground mountain slope, in June-July, 2006. Prof. Jamsran Ts., Department of Botany, National University of Mongolia authenticated these plant species. Voucher specimens (Df 0406, Ma 0708, Sh 0607) have been deposited in the Herbariums of Natural Product 
Chemistry Laboratory of ICCT, MAS.

Extraction and fractionation: Air dried and chopped crude drugs of D.fruticosa, M.alopecuroides and S.hybridum were extracted separately with $80 \%$ ethanol at room temperature exhaustively. Each total ethanol extract was filtered and concentrated under vacuum at $40^{\circ} \mathrm{C}$ to give the thick residue which was re-suspended in distilled water and further fractionated successively with equal volume of dichloromethane (DCM), ethylacetate (EA) and $n$-butanol $(n-\mathrm{BuOH})$ (Table 1). formation of acid stable complex with $2 \% \mathrm{AlCl}_{3}$ at 401.5 and $430.0 \mathrm{~nm}$. Results were expressed as rutin (Sigma Inc.) and quercetin ( $\mathrm{TCl}$ Co., Ltd) equivalents (RE and QE) from the calibration curve $[16,17]$. The content of total tannins was determined by spectrophotometry using a hide powder and the Folin Ciocalteu reagent in $\mathrm{pH}<10$, at $760 \mathrm{~nm}$. Results were expressed as pyrogallol (Sigma Inc.) equivalent (PE) from the calibration curve [18].

DPPH scavenging activity: DPPH radical (2,2-diphenyl2-picrylhydrazyl hydrate, TCl, Co., Ltd) scavenging activity

Table 1. Yield of extracts and fractions, $g$

\begin{tabular}{lcccccc}
\hline Plant samples & $\begin{array}{c}\text { Weight of } \\
\text { drugs }\end{array}$ & $\begin{array}{c}\text { Thick } \\
\text { extract }\end{array}$ & $\begin{array}{c}\text { DCM } \\
\text { fraction }\end{array}$ & EA fraction, & $\begin{array}{c}\text { n-BuOH } \\
\text { fraction }\end{array}$ & $\begin{array}{c}\text { Water } \\
\text { residue }\end{array}$ \\
\hline D.fruticosa (Df) flowers & 300.0 & 93.0 & 5.1 & 25.8 & 17.3 & 40.0 \\
$\begin{array}{l}\text { D.fruticosa (Df) leaves } \\
\text { M.alopecuroides (Ma) }\end{array}$ & 300.0 & 46.0 & 9.1 & 9.5 & 16.3 & 4.0 \\
branches & 3500.0 & 818.0 & 68.4 & 40.0 & 250.0 & 200.0 \\
S.hybridum (Sh) herb & 1450.0 & 300.0 & 2.0 & 31.5 & 126.0 & 140.0 \\
\hline
\end{tabular}

Each crude drug (50 g) was extracted twice with distilled water at room temperature and evaporated to dryness in vacuo. Then they were tested for their biological activities. Isolation and identification: The EA fractions of Df flowers $(25.5 \mathrm{~g})$ and Sh herb $(28.0 \mathrm{~g})$, the EA and n-BuOH fractions of the Ma branch ( 35.0 and $30.0 \mathrm{~g}$ ) were divided into several subfractions using $\mathrm{CC}$ with Sephadex $\mathrm{LH}$ 20 , eluting with a mixture of $50 \% \mathrm{DCM}$ in $\mathrm{MeOH}$. Each subfraction was subjected to $\mathrm{CC}$ with different absorbents as $75-150 \mu \mathrm{m}$ CHP 20P, and reversed phase sepra ${ }^{\mathrm{TM}}$ C18-E $(50 \mu \mathrm{m})$ eluting with gradient $\mathrm{H}_{2} \mathrm{O}-\mathrm{MeOH}$ system, respectively. The final purification of substances was reached by repeated CC with Sephadex LH 20.

The DCM fractions of Ma branch $(30.0 \mathrm{~g})$, Df flowers $(3.5 \mathrm{~g})$ and Sh herb $(1.0 \mathrm{~g})$ were divided into numerous subfractions by CC with silica gel $60(40-60 \mu \mathrm{m})$, eluting with $n$-hexane: DCM - 7:3 $\rightarrow 6: 4 \rightarrow 5: 5 \rightarrow 3: 7 \rightarrow 1: 9 \mathrm{v} / \mathrm{v}$, and DCM: EA - 10:1 $\rightarrow 95: 5 \rightarrow 9: 1 \mathrm{v} / \mathrm{v}$, respectively. The subfractions were separated repeatedly over silica gel columns eluted gradiently with solvent systems such as $n$-hexane : $\mathrm{EA}, \mathrm{CHCl}_{3}: \mathrm{MeOH}$ and DCM : $\mathrm{MeOH}$.

From all three plant species compounds (see Fig. 2) 1 (0.34 g), 10 (0.42 g), 23 (0.39 g), 31 (0.50 g), 32 (0.17 g) $34(0.44 \mathrm{~g})$, from Df and Ma, compound $4(0.45 \mathrm{~g})$, from Df and Sh compound 6 (66.8 $\mathrm{mg})$, from $\mathrm{Ma}$ and $\mathrm{Sh}$ compounds $24(0.36 \mathrm{~g})$ and $\mathbf{3 5}(0.31 \mathrm{~g})$ have been isolated and identified. Only from Df compounds $2(2.1 \mathrm{~g}), 3(0.22$ g), 5 (0.88 g), 11 (62.7 mg), 12 (0.48 g), 20 (0.20 g), 21 $(0.34 \mathrm{mg})$ and $\mathbf{3 0}(8.0 \mathrm{mg})$, from Ma compounds 7 (7.6 $\mathrm{mg}), 8(24.0 \mathrm{mg}), \boldsymbol{9}(24.0 \mathrm{mg}), 13(0.18 \mathrm{~g}), 14(0.19 \mathrm{~g}), 17$ $(1.19 \mathrm{~g}), 27(1.38 \mathrm{~g})$ and $29(0.28 \mathrm{~g})$, from Sh compounds 15 (5.0 mg), 16 (26.2 mg), 18 (64.4 mg), 19 (33.7 mg), 22 $(0.30 \mathrm{~g}) 25(0.22 \mathrm{~g}), 26(60.6 \mathrm{mg}), 28(22.3 \mathrm{mg})$ and 33 $(67.8 \mathrm{mg})$ have been isolated and identified.

Quantitative analysis of total phenolics, flavonoids and tannins: The content of total phenolics in all crude drugs was measured by means of the Folin Ciocalteu reagent in $\mathrm{pH}<10$, at $760 \mathrm{~nm}$ on a spectrophotometer. Results were expressed as gallic acid (Sigma Inc.) equivalent (GAE) from the calibration curve $[14,15]$. The amount of total flavonoids was determined by spectrophotometry using a of the crude extracts, fractions and pure compounds was determined according to the known spectrophotometric assay [19]. The absorbance was measured at $517 \mathrm{~nm}$ and the anti-oxidativeactivity (AA) was expressed in percentage:

$$
\mathrm{AA} \%=100-\left\{\left[\left(\mathrm{Abs}_{\text {sample }}-\mathrm{Abs}_{\text {blank }}\right) \times 100\right] / \mathrm{Abs}_{\text {control }}\right\} ;
$$

Methanol $(1.5 \mathrm{ml})$ added to plant extract solution $(1.5 \mathrm{ml})$ was used as a blank. DPPH solution $\left(1.5 \mathrm{ml}, 6 \times 10^{-5} \mathrm{M}\right)$ plus methanol $(1.5 \mathrm{ml})$ was used as a control and rutin was used as a positive control.

Acetylcholinesterase inhibiting activity: The acetylcholinesterase (AChE) inhibiting activity of crude extracts, fractions and isolated pure substances was determined using a previously reported Ellman spectrophotometric method with DTNB (5,5'-dithiobis(2nitrobenzoisc acid), TCI, Co., Ltd) color reagent [20]. The absorbance was measured at $412 \mathrm{~nm}$ and the AChE inhibiting activity (I) was expressed in percentage:

$$
\begin{aligned}
\text { I }(\%)=100 \times\left(\Delta \mathrm{Abs}_{\text {control }}-\Delta \mathrm{Abs}_{\text {sample }}\right) / \Delta \mathrm{Abs}_{\text {control }} \\
\text { Where, } \Delta \mathrm{A}_{\text {control }}=\mathrm{Abs}_{\text {positive control }}-\mathrm{Abs}_{\text {blank positive control }} \\
\Delta \mathrm{A}_{\text {sample }}=\mathrm{Abs}_{\text {sample }}-\mathrm{Abs}_{\text {blank sample }}
\end{aligned}
$$

Blank solution was prepared from $0.1 \mathrm{ml}$ sample $(1 \mathrm{mg} / \mathrm{ml})$ with DTNB prepared in Tris- $\mathrm{HCl}$, while the positive control was prepared from DMSO (dimethylsulfoxide) with the same amount of the sample. Eserin (physostigmine, TCl, Co., Ltd) was used as a positive control.

Pancreatic lipase inhibiting activity: The pancreatic lipase (PL) enzyme inhibiting activity of crude extracts, fractions and isolated pure substances was determined using a spectrophotometric method with DTNB color reagent [21]. The absorbance was measured at $412 \mathrm{~nm}$ and the PL inhibiting activity (I) was expressed in percentage:

$$
I(\%)=\left(1-\mathrm{Abs}_{\text {sample }} / \mathrm{Abs}_{\text {blank }}\right) \times 100 \text {; }
$$

Blank solution was prepared from $0.1 \mathrm{ml}$ of water with 
DTNB prepared in Tris- $\mathrm{HCl}$ and porcine pancreatic lipase was prepared in water in the same amount as the sample analysis. Orlistat (TCl, Co., Ltd), a selective inhibitor for $\mathrm{PL}$, was used as a positive control.

Statistical analysis: All data are expressed in mean \pm standard deviation (S.D).

The $\mathrm{IC}_{50}$ value, defined as the amount of the sample that could reduce the initial concentration of DPPH, PL and AChE by $50 \%$, was calculated from the linear regression plots of test samples concentration $(\mu \mathrm{g} / \mathrm{mL}$ and $\mathrm{mg} / \mathrm{mL}$ ) against the mean inhibition in percentage. $I C_{50}$ values were calculated using concentration of tested plant extracts, fractions and isolated substances and average percent of the antioxidant activity from three separate tests, PL and AChE inhibiting activities 6-8 separate tests.

\section{RESULTS AND DISCUSSION}

In general, the polar EA fractions of all investigated crude drugs of D.fruticosa, M.alopecroides and S.hybridum exhibited better anti-oxidative activity by the DPPH scavenging method and the inhibition activity against AChE and PL enzymes (Figure 1).

In particular, the $1 C_{50}$ value $(\mathrm{mg} / \mathrm{ml})$ of the $E A$ fraction of D.fruticosa leaves for scavenging of $\mathrm{DPPH}$ was determined as $24.11 \pm 0.25$, which is the greatest among the all studied samples, compared to the positive control rutin (22.66 \pm 0.29$)$. The EA and $n-\mathrm{BuOH}$ fractions of the branch of M.alopecuroides $(27.11 \pm 0.58$ and $26.14 \pm 0.31)$ and the herb of S.hybridum $(28.63 \pm 0.32$ and $29.13 \pm 0.13)$ showed comparable results. The $\mathrm{EtOH}$ and water extracts, including the $n-\mathrm{BuOH}$ fraction of $D$.fruticosa samples gave almost twice lower activities than rutin. The ethanol extracts of M.alopecuroides and S.hybridum gave comparable results $(31.93 \pm 0.48$ and $35.61 \pm 0.36)$, which were better than the activity of related water extracts $(52.35 \pm 0.85$ and $48.59 \pm 0.64)$. The AChE inhibition percentage of all assayed samples at the $1 \mathrm{mg} / \mathrm{ml}$ concentration was considerably less than the positive control eserin, which can inhibit by $100 \%$ at the $0.1 \mathrm{mg} / \mathrm{ml}$. However, in this tested concentration the EtOH extract, EA and $n-\mathrm{BuOH}$ fractions of $D$.fruticosa leaves, as well as the EA fraction of the branch of M.alopecuroides could inhibit by over $60 \%$, while activities of other samples were in the $40-59 \%$ range. The PL inhibition percentages of all assayed samples were less than the positive control orlistat $(62.5 \pm 1.27 \%)$ at the same $1 \mathrm{mg} / \mathrm{ml}$ concentration. The EA fractions of flowers and leaves of $D$.fruticosa gave the best activity as $50.25 \pm 0.86 \%$ and $48.82 \pm 1.27 \%$, respectively, which were the closest results to orlistat. Whereas, the EA fractions of two other plant species and all EtOH extracts exhibited ca. 2-1.5 times lower activity than the positive control.

Nonpolar DCM fractions of all assayed samples did not contribute any effect to scavenging of DPPH, inhibiting of AChE and PL enzymes.

Results of biological activity experiments indicate that the EtOH extracts of all assayed plant samples exhibited better activity than the related water extracts and biologically active key components are presented in the polar EA and $n-\mathrm{BuOH}$ fractions.

Considering the results of biological activity assays and qualitative analysis, the total phenolics, flavonoids and tannins were determined by the spectrophotometric methods (Table 2). Total phenolics in flowers EtOH $(17.05 \pm 0.96 \%)$ and water $(14.80 \pm 1.41 \%)$ extracts of $D$.fruticosa were estimated in the highest amount among the ethanol and water extracts of all investigated samples. The amount of total flavonoids in the EtOH extract of $D$.fruticosa flowers was determined in rutin equivalent as $5.30 \pm 0.57 \%$, which is more than twice higher than the EtOH extracts of two other plant species, while in quercetin equivalent as $5.89 \pm 0.11 \%$, which is 3-9 times higher than the related extracts. The branch of M.alopecuroides was

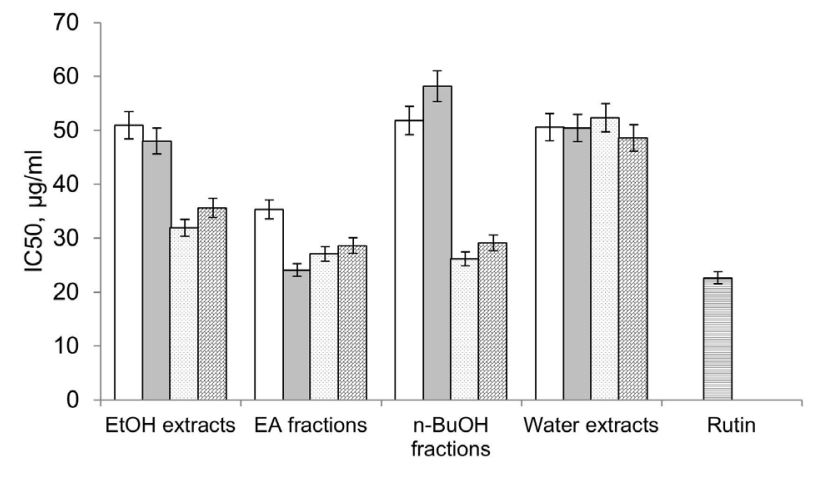

A. DPPH scavenging activity
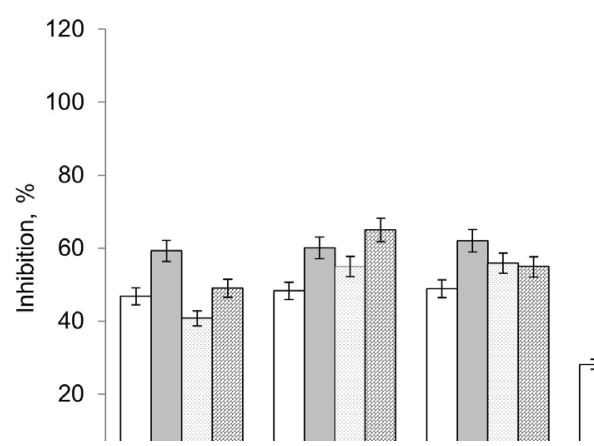

Fig. 1. Biological activities of crude extracts and fractions

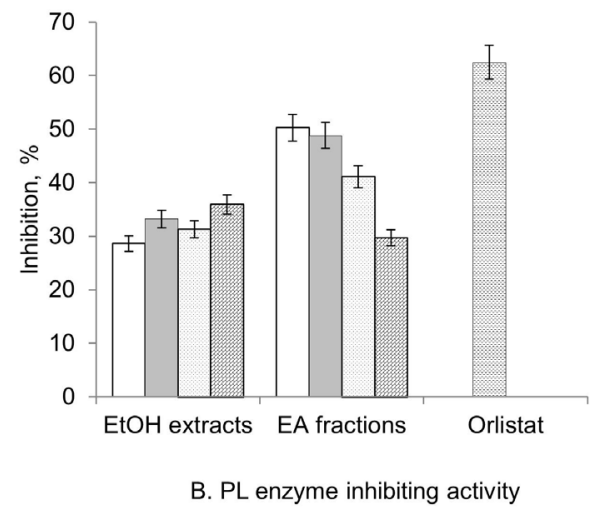

$\square$ Df flowers

aDf leaves

$\square$ Sh herb

Ma branch 
Table 2. Quantity of main components, \%

\begin{tabular}{|c|c|c|c|c|c|c|}
\hline & \multirow{2}{*}{ Samples } & & \multirow{2}{*}{$\begin{array}{l}\text { Total phenolics } \\
\text { (in GAE) }\end{array}$} & \multicolumn{2}{|c|}{ Total flavonoids } & \multirow{2}{*}{$\begin{array}{l}\text { Total tannins } \\
\quad \text { (in PE) }\end{array}$} \\
\hline & & & & (in RE) & (in QE) & \\
\hline \multirow{4}{*}{$\begin{array}{l}\text { Dasiphora } \\
\text { fruticosa Rydb. }\end{array}$} & \multirow[t]{2}{*}{ Flowers } & EtOH extract & $17.05 \pm 0.96$ & $5.30 \pm 0.57$ & $5.89 \pm 0.11$ & \multirow{2}{*}{$4.88 \pm 0.15$} \\
\hline & & Water extract & $14.80 \pm 1.41$ & $5.17 \pm 0.16$ & $2.90 \pm 0.09$ & \\
\hline & \multirow[t]{2}{*}{ Leaves } & EtOH extract & $12.16 \pm 0.74$ & $4.51 \pm 0.22$ & $4.36 \pm 0.13$ & \multirow{2}{*}{$3.40 \pm 0.07$} \\
\hline & & Water extract & $8.45 \pm 1.92$ & $2.42 \pm 0.08$ & $2.76 \pm 0.01$ & \\
\hline $\begin{array}{l}\text { Myricaria } \\
\text { alopecuroides } \\
\text { Schrenk. }\end{array}$ & Branch & EtOH extract & $15.14 \pm 1.48$ & $2.09 \pm 0.03$ & $0.61 \pm 0.02$ & $5.33 \pm 0.11$ \\
\hline $\begin{array}{l}\text { Sedum } \\
\text { hybridum L. }\end{array}$ & Herb & EtOH extract & $9.44 \pm 0.62$ & $1.98 \pm 0.07$ & $1.54 \pm 0.03$ & $3.32 \pm 0.05$ \\
\hline
\end{tabular}

specified by containing rather more amounts of tannins $(5.33 \pm 0.11 \%)$, while its quantity of total phenolics was almost comparable to flowers and leaves of D.fruticosa. The EtOH extract of the herb of S.hybridum contains a bit lower amount of phenolics and tannins $(9.44 \pm 0.62 \%$ and $3.32 \pm 0.05 \%$ ) than other two plants related samples, while the amount of flavonoids was close to M.alopecuroides. Consequently, the qualitative and quantitative analysis of these three species indicated that they could classify to the phenolics containing plants.

The biological activity results guide to isolate and identify altogether 35 known compounds from the flowers of $D$.fruticosa, from the branch of M.alopecuroides and from the herb of S.hybridum (Figure 2, Table 3). Among them, 29 phenolics, namely, quercetin-, kaempferol-, myricetinaglycones and glycosides, gossypetin-, herbacetinand apigenin-glycosides (1-20), (+)catechin (21), (-) epigallocatechingallate (EGCG) (22), gallic acid (23), ethylgallate (24), 6-O-galloylarbutin (25), 2,4,6-trigalloylO- $\beta$ - $D$-glucopyranose (26), tellimagrandin II (27), caffeic acid (28) and ferulic acid (29) have been isolated from the $\mathrm{EA}$ and $n-\mathrm{BuOH}$ fractions of three plant samples. Whereas, other 6 compounds as fatty acids, ursolic acid and sterols $(30-35)$ have been isolated from DCM fractions.

Quercetin glycosides (2-6) were evaluated as characteristic phytochemicals in flowers and leaves of D.fruticosa, while isorhamnetin (17), ethyl gallate (24) and tellimagrandin II (27) were specified the branch of M.alopecoroides. The herb of S.hybridum was differed from other two plants by containing of myricetin-, gossypetin-, herbacetin- aglycones and glycosides (1519), and (-)EGCG (22). In the meantime, quercetin (1), kaempferol (10) and gallic acid (23) were found to be as common metabolites in these investigated plants. Another aim of this study was to evaluate the DPPH scavenging activity and the inhibitory effects against $A C h E$ and PL of isolated compounds (Table 3).

Generally, the anti-oxidative activity of flavonoids and phenolic compounds was studied very well by various methods [51]. According to the DPPH scavenging experiment 12 compounds, including quercetin glycosides (2-7), gossypetin-8- $\beta-D$-xylopyranoside (19), (+)catechin (21), (-)EGCG (22), gallic acid (23), 2,4,6-trigalloyl-O- $\beta$ - $D$ glucopyranose (26) and tellimagrandin II (27) exhibited a strong activity, which was better than the positive control rutin $\left(\mathrm{IC}_{50}, 38.7 \mu \mathrm{M}\right)$. Especially, it was clearly notable that compounds $27\left(\mathrm{IC}_{50}, 5.97 \mu \mathrm{M}\right), 7\left(\mathrm{IC}_{50}, 13.40 \mu \mathrm{M}\right), 6\left(\mathrm{IC}_{50}\right.$,
$17.45 \mu \mathrm{M})$ and $26\left(\mathrm{IC}_{50}, 17.91 \mu \mathrm{M}\right)$ showed by $6.5-2.2$ times higher activity than rutin. Among the active flavonol derivatives quercetin glycosides (2-7) exhibited better activity than 19, as well as 10,17, 15, 16 and 18. Molecular structures of all active compounds were distinguished by the presence of number of hydroxy groups, a 2,3-double bond, orthodiphenolicstructureandgallatemoieties. Thestructureactivity relationship for antioxidation and scavenging of radicals was well studied and documented [52-54]. Thirty four isolated compounds have been tested for their AChE inhibitory activity by the Ellman method [20]. None of the compounds exhibited activity against AChE like the potential drug physostigmine, which was used as the positive control. However, quercetin and its glycosides (1-8), kaempferol-, myricetin-, herbacetin-, gossypetin glycosides $(12,16,18,19)$ and (-)EGCG $(22)$ were found to be more active than others. On the other hand, they inhibited AChE at the concentration $0.5 \mathrm{mg} / \mathrm{mL}$ by over $50 \%$, which was comparable with the results reported previously $[55,56]$. Gallic acid derivatives $\mathbf{2 6}$ and $\mathbf{2 7}$ exerted a weak inhibitory activity against AChE rather than their DPPH scavenging activity. Gallic acid (23) and ethylgallate (24) were not active against AChE (see Table 3 ). Hence, it is noticed that both flavonols and gallic acid derivatives showed the strong anti-oxidative activity. However, flavonolos have exhibited remarkable AChE inhibitory effect, whereas effect of gallic acid derivatives on AChE was minimal. To date 128 flavonoids were found to possess AChE inhibitory activity [56]. In this study flavonoid derivatives 3-6, 9, 12-14, 16-21 and an other class of compounds 24-35 have been investigated for their AChE inhibitory activity for the first time. The PL enzyme inhibition activity assay of all isolated compounds demonstrated that only $22\left(\mathrm{IC}_{50}, 0.1 \mathrm{mM}\right)$ and $27\left(\mathrm{IC}_{50}, 0.051 \mathrm{mM}\right)$, including compound $26\left(\mathrm{IC}_{50}, 0.116\right.$ $\mathrm{mM}$ ) were active in the same dose of the positive control orlistat. Moreover, compounds 25 and $26\left(\mathrm{IC}_{50}, 0.236\right.$ $\mathrm{mM}$ and $0.267 \mathrm{mM}$ ) have demonstrated slightly more activity than the other components. Structures of these compounds were differed from the rest of components by the presence of multihydroxy groups and esterified galloyl moities, which are essential for the PL enzyme inhibition [57-59].

It is noteworthy that kaempferol glycosides (11-14) did not show any activity for scavenging of DPPH. Kaempferol and its glycosides $(10,11,13,14)$, including 17, 20, 21, 23, 24 and $\mathbf{2 8}$ were also not active for the inhibition of AChE 


\begin{tabular}{|c|c|c|c|c|c|c|}
\hline & $\mathrm{R}_{1}$ & $\mathrm{R}_{2}$ & $R_{3}$ & $\mathrm{R}_{4}$ & $\mathrm{R}_{5}$ & Ref \\
\hline 1 & $\mathrm{OH}$ & $\mathrm{H}$ & $\mathrm{H}$ & $\mathrm{OH}$ & $\mathrm{H}$ & 22,23 \\
\hline 2 & O- $\alpha-L$-arabinopyranoside & $\mathrm{H}$ & $\mathrm{H}$ & $\mathrm{OH}$ & $\mathrm{H}$ & 22,24 \\
\hline 3 & O-(6'-galloyl)- $\beta$ - $D$-galactopyranoside & $\mathrm{H}$ & $\mathrm{H}$ & $\mathrm{OH}$ & $\mathrm{H}$ & 22 \\
\hline 4 & $\mathrm{O}-\beta$-D-glucuronide & $\mathrm{H}$ & $\mathrm{H}$ & $\mathrm{OH}$ & $\mathrm{H}$ & 25,26 \\
\hline 5 & $O-\beta$-D-galactopyranoside & $\mathrm{H}$ & $\mathrm{H}$ & $\mathrm{OH}$ & $\mathrm{H}$ & 27 \\
\hline 6 & O-L-arabinofuranoside & $\mathrm{H}$ & $\mathrm{H}$ & $\mathrm{OH}$ & $\mathrm{H}$ & 27 \\
\hline 7 & O- $\beta$-D-glucopyranoside & $\mathrm{H}$ & $\mathrm{H}$ & $\mathrm{OH}$ & $\mathrm{H}$ & 28 \\
\hline 8 & O- $\alpha-L$-rhamnopyranoside & $\mathrm{H}$ & $\mathrm{H}$ & $\mathrm{OH}$ & $\mathrm{H}$ & 29 \\
\hline 9 & $O-\beta$-D-glucuronide methyl ester & $\mathrm{H}$ & $\mathrm{H}$ & $\mathrm{OH}$ & $\mathrm{H}$ & 30 \\
\hline 10 & $\mathrm{OH}$ & $\mathrm{H}$ & $\mathrm{H}$ & $\mathrm{H}$ & $\mathrm{H}$ & 27,28 \\
\hline 11 & O- $\beta$-D-glucopyranoside & $\mathrm{H}$ & $\mathrm{H}$ & $\mathrm{H}$ & $\mathrm{H}$ & 31 \\
\hline 12 & O-(6'-coumaroyl)- $\beta$-D-glucopyranoside & $\mathrm{H}$ & $\mathrm{H}$ & $\mathrm{H}$ & $\mathrm{H}$ & 32 \\
\hline 13 & O- $\alpha-L$-rhamnopyranoside & $\mathrm{H}$ & $\mathrm{H}$ & $\mathrm{H}$ & $\mathrm{H}$ & 29 \\
\hline 14 & $O-\beta$-D-glucuronide & $\mathrm{H}$ & $\mathrm{H}$ & $\mathrm{H}$ & $\mathrm{H}$ & 33 \\
\hline 15 & $\mathrm{OH}$ & $\mathrm{H}$ & $\mathrm{H}$ & $\mathrm{OH}$ & $\mathrm{OH}$ & 34 \\
\hline 16 & O- $\alpha$-L-arabinofuranoside & $\mathrm{H}$ & $\mathrm{H}$ & $\mathrm{OH}$ & $\mathrm{OH}$ & 35 \\
\hline 17 & $\mathrm{OH}$ & $\mathrm{H}$ & $\mathrm{H}$ & $\mathrm{OCH}_{3}$ & $\mathrm{H}$ & 27,36 \\
\hline 18 & $\mathrm{OH}$ & $\mathrm{H}$ & O- $\beta$ - $D$-xylopyranoside & $\mathrm{H}$ & $\mathrm{H}$ & 37,38 \\
\hline 19 & $\mathrm{OH}$ & $\mathrm{H}$ & O- $\beta$-D-xylopyranoside & $\mathrm{OH}$ & $\mathrm{H}$ & 38 \\
\hline 20 & $\mathrm{H}$ & $\begin{array}{l}\text { O-(6'-coumaroyl)- } \beta-D- \\
\text { glucopyranoside }\end{array}$ & $\mathrm{H}$ & $\mathrm{H}$ & $\mathrm{H}$ & 39 \\
\hline
\end{tabular}<smiles>Oc1cc(O)c2c(c1)O[C@H](c1ccc(O)c(O)c1)[C@H](O)C2</smiles>

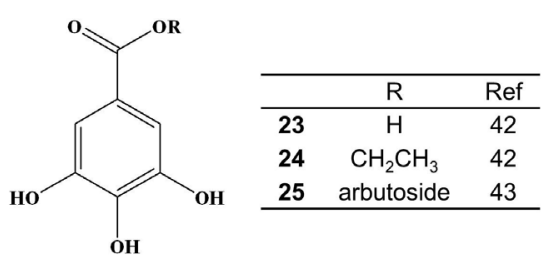

21 [40]<smiles>O=C(O[C@@H]1Cc2c(O)cc(O)cc2O[C@H]1c1cc(O)c(O)c(O)c1)c1cc(O)c(O)c(O)c1</smiles>

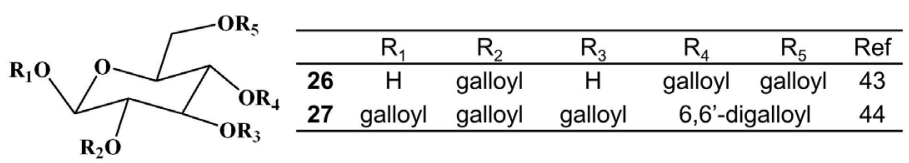

22 [41]<smiles>O=C(O)/C=C/c1ccc(O)c(O)c1</smiles>

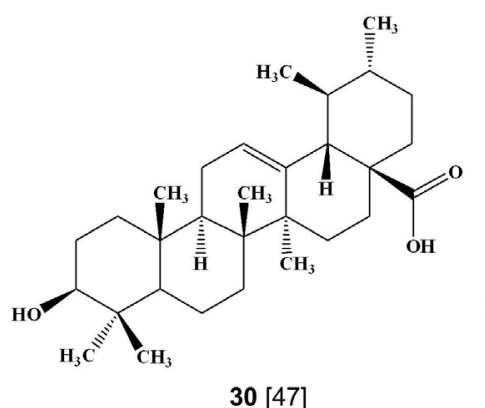

$30[47]$

$\mathrm{C}_{15} \mathrm{H}_{31} \mathrm{COOH}$

$33[50]$

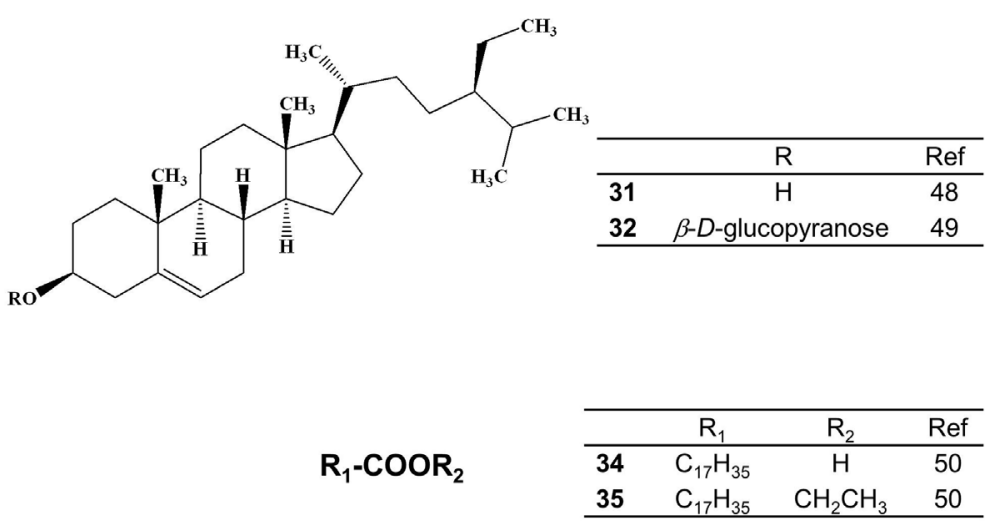

Fig. 2. Structures of isolated compounds 
Table 3. Isolated compounds and their biological activities

\begin{tabular}{|c|c|c|c|c|c|}
\hline Code & Compounds and references & Sources & $\begin{array}{c}\text { DPPH } \\
\text { scaven-ging } \\
\text { activity } \\
\mathrm{IC}_{50}, \mu \mathrm{M}\end{array}$ & $\begin{array}{l}\text { AChE inhibiting } \\
\text { activity, } \mathrm{IC}_{50}, \mathrm{mM}\end{array}$ & $\begin{array}{l}\text { PL inhibiting } \\
\text { activity, } \mathrm{IC}_{50}, \mathrm{mM}\end{array}$ \\
\hline & & & $\begin{array}{c}\text { Rutin } \\
\mathrm{IC}_{50}, 38.7 \mu \mathrm{M}\end{array}$ & $\begin{array}{l}\text { Physostigmine } \\
\mathrm{IC}_{50}, \mathbf{0 . 0 0 0 0 8 3 \mathrm { mM }}\end{array}$ & $\begin{array}{c}\text { Orlistat } \\
\mathrm{IC}_{50}, 0.109 \mathrm{mM}\end{array}$ \\
\hline 1 & Quercetin & Df, Sh, Ma & $41.36 \pm 0.89$ & $0.098 \pm 0.001$ & $1.784 \pm 0.030$ \\
\hline 2 & Quercetin-3-O- $\alpha-L$-arabinopyranoside & Df & $28.59 \pm 0.11$ & $0.021 \pm 0.003$ & $1.865 \pm 0.027$ \\
\hline 3 & $\begin{array}{l}\text { Quercetin-3-O-(6"-galloyl)- } \beta \text { - } D \text {-galacto- } \\
\text { pyranoside }\end{array}$ & Df & $31.68 \pm 0.07$ & $0.036 \pm 0.001$ & $1.026 \pm 0.060$ \\
\hline 4 & Quercetin-3-O- $\beta$-- $D$-glucuronide & Df, Ma & $24.30 \pm 0.27$ & $0.077 \pm 0.002$ & $1.191 \pm 0.018$ \\
\hline 5 & Quercetin-3-O- $\beta$ - $D$-galactopyranoside & Df & $25.77 \pm 0.76$ & $0.021 \pm 0.002$ & $1.644 \pm 0.101$ \\
\hline 6 & Quercetin-3-O- $\alpha$ - $L$-arabinofuranoside & Df, Sh & $17.45 \pm 0.28$ & $0.047 \pm 0.003$ & $1.665 \pm 0.032$ \\
\hline 7 & Quercetin-3-O- $\beta$ - $D$-glucopyranoside & Ma & $13.40 \pm 1.04$ & $0.041 \pm 0.001$ & $1.991 \pm 0.02 ?$ \\
\hline 8 & Quercetin-3-O- $\alpha$-L-rhamnopyranoside & Ma & ns & $0.073 \pm 0.005$ & $1.514 \pm 0.011$ \\
\hline 9 & Quercetin-3-O- $\beta--D$-glucuronide methylat & $\mathrm{Ma}$ & ns & $0.136 \pm 0.007$ & $1.192 \pm 0.044$ \\
\hline 10 & Kaempferol & Df, Sh, Ma & $86.70 \pm 1.13$ & $0.507 \pm 0.016$ & $1.239 \pm 0.041$ \\
\hline 11 & Kaempferol-3-O- $\beta-D$-glucopyranoside & Df & na & $0.188 \pm 0.009$ & $1.782 \pm 0.023$ \\
\hline 12 & $\begin{array}{l}\text { Kaempferol-3-O- } \beta-D-(6 "-n \text {-coumaroyl)- } \\
\text { glucopyranoside }\end{array}$ & Df & na & $0.030 \pm 0.003$ & $1.200 \pm 0.037$ \\
\hline 13 & Kaempferol-3-O- $\alpha$ - $L$-rhamnopyranoside & Ma & na & $0.349 \pm 0.011$ & $1.804 \pm 0.072$ \\
\hline 14 & Kaempferol-3-O- $\beta-D$ - glucuronide & Ma & na & $0.322 \pm 0.006$ & $1.161 \pm 0.021$ \\
\hline 15 & Myricetin & Sh & $54.60 \pm 1.14$ & ns & ns \\
\hline 16 & Myricetin-3-O- $\alpha$ - $L$-arabinofuranoside & Sh & $41.95 \pm 0.13$ & $0.081 \pm 0.001$ & $1.267 \pm 0.027$ \\
\hline 17 & Isorhamnetin & Ma & $68.42 \pm 0.02$ & $0.253 \pm 0.007$ & $1.667 \pm 0.042$ \\
\hline 18 & Herbacetin-8-O- $\beta-D$-xylopyranoside & Sh & $50.17 \pm 1.17$ & $0.051 \pm 0.001$ & $1.116 \pm 0.011$ \\
\hline 19 & Gossypetin-8-O- $\beta-D$-xylopyranoside & Sh & $35.18 \pm 0.95$ & $0.043 \pm 0.001$ & $1.315 \pm 0.045$ \\
\hline 20 & $\begin{array}{l}\text { Apigenin-7-O- } \beta-D-(6 "-n \text {-coumaroyl) } \\
\text { gluco-pyranoside }\end{array}$ & Df & ns & $0.325 \pm 0.007$ & $1.076 \pm 0.094$ \\
\hline 21 & $(+)$ Catechin & Df & $36.21 \pm 0.04$ & $1.042 \pm 0.027$ & $0.565 \pm 0.024$ \\
\hline 22 & (-) Epigallocatechin-gallate & Sh & $19.63 \pm 0.21$ & $0.075 \pm 0.006$ & $0.100 \pm 0.071$ \\
\hline 23 & Gallic acid & Df, Sh, Ma & $30.90 \pm 1.21$ & $2.582 \pm 0.017$ & $0.886 \pm 0.012$ \\
\hline 24 & Ethylgallate & Sh, Ma & $53.94 \pm 1.20$ & $1.907 \pm 0.071$ & $0.236 \pm 0.010$ \\
\hline 25 & 6-O-galloylarbutin & Sh & $49.69 \pm 0.70$ & $0.141 \pm 0.006$ & $0.267 \pm 0.070$ \\
\hline 26 & $2,4,6$-trigalloyl-O- $\beta$ - $D$-glucopyranose & Sh & $17.91 \pm 0.28$ & $0.213 \pm 0.002$ & $0.116 \pm 0.022$ \\
\hline 27 & Tellimagrandin II & Ma & $5.97 \pm 0.52$ & $0.382 \pm 0.003$ & $\mathbf{0 . 0 5 1 \pm 0 . 0 0 1}$ \\
\hline 28 & Caffeic acid & Sh & $58.93 \pm 1.01$ & $5.121 \pm 0.021$ & $0.774 \pm 0.001$ \\
\hline 29 & Ferulic acid & Ma & na & $1.370 \pm 0.027$ & $0.772 \pm 0.007$ \\
\hline 30 & Ursolic acid & Df & na & $0.306 \pm 0.003$ & $1.647 \pm 0.022$ \\
\hline 31 & $\beta$-Sitosterol & Df, Sh, Ma & na & $0.670 \pm 0.007$ & $3.329 \pm 0.025$ \\
\hline 32 & $\beta$-Sitosterylglucopyra-nose & Df, Sh, Ma & na & $0.202 \pm 0.011$ & $1.864 \pm 0.071$ \\
\hline 33 & Palmitic acid & Df, Sh & na & $0.575 \pm 0.023$ & $4.824 \pm 0.017$ \\
\hline 34 & Stearic acid & Df, Sh, Ma & na & $1.080 \pm 0.053$ & $3.715 \pm 0.081$ \\
\hline 35 & Stearic acid ethylate & Sh, Ma & na & $1.580 \pm 0.017$ & $2.483 \pm 0.071$ \\
\hline
\end{tabular}

Notice: Df - flower; Sh - herb; Ma - branch; na - not active; ns - not screened;

enzyme. All flavonoid derivatives (1-20) showed no activity against PL enzyme. Moreover, compounds 29-35 did not exhibit any activity against all tested biological activities. Only (-)EGCG, well known green tea component, has been found to be the active component. (-)EGCG exhibited as a potential antioxidant by the scavenging of DPPH, an active inhibitor against AChE enzyme or the supporter for the brain cognition function and an excellent inhibitor for the PL enzyme or preventer against accumulation of lipids. Previously, Zhao et al. [60], Okello et al. [61] and Nakai et al. [62] reported about these three activities of (-)EGCG. 


\section{CONCLUSIONS}

The flowers and leaves of Dasiphora fruticosa, the branch of Myricaria alopecuroides and the herb of Sedum hybridum were rich in phenolics, which were identified as the major bio-active characteristic compounds. Quercetin-, myricetin-, gossypetin glycosides, kaempferol3-O- $\beta$ - $D$-(6"-coumaroyl)glucopyranoside and (-)EGCG exhibited as active inhibitors against the AChE enzyme associated with the anti-oxidative activity. Whereas, multigalloylglucopyranose derivatives and (-)EGCG demonstrated to be as the active inhibitors against the PL enzyme associated with the anti-oxidative activity.

Consequently, the flowers of Dasiphora fruticosa and the herb of Sedum hybridum could be identified as antioxidants and AChE enzyme inhibitors, the branch of Myricaria alopecuroides as the antioxidant and the PL enzyme inhibitor. Therefore, the crude drugs of these plants could be studied further in view of their potential uses as anti-oxidative, brain anti-aging and lipid lowering active product

\section{ACKNOWLEDGEMENT}

The author is thankful for financial support by InterInstitutional Collaboration Research Program under Korea Research Council for Industrial Science and Technology and Mongolian Foundation for Science and Technology.

\section{REFERENCES}

1. Ligaa U., Davaasuren B., Ninjin N., (2005) Medicinal plants of Mongolia used in western and eastern medicine, JKC Printing, Ulaanbaatar, 480 pp.

2. Plant resources USSR, Family: Hydrangenaceae Haloragaceae (1987). Nauka Press, 68.

3. Plant resources USSR, Family: Paeoneaceae Thymelaeaceae (1986). Nauka Press, 2, 98-100.

4. Khaidav Ts., Menshikova T.A., (1978) Medicinal plants in Mongolian medicine, State Press, Ulaanbaatar, 192.

5. Plant resources of Russia. Flowering wild plants, their phytochemical constituents and biological activities. Family Crassulaceae (2009), Saint Peterburg, KMK press, 2, 200-206.

6. Fedoseeva G.M., (1979) Phenolics from Potentilla fruticosa L., Chem. Nat. Prods, 4, 575-576.

7. Ganenko T.B., Semenov A.A., (1988) Chemical composition of Potentilla fruticose, Flavonoids, Chem. Nat. Prods., 3, 451-452.

8. Chumbalaov T.K., Bukbulatova T.N., Iliyasova M.I.(1973) Polyphenols of Myricaria alopecuroides, Chem. Nat. Prods., 3, 421.

9. Chumbalaov T.K., Bukbulatova T.N., Iliyasova M.I. (1975) Polyphenols of Myricaria alopecuroides, III. Hydrolyzable tanning substances, Chem. Nat. Prods., 1, 131-132.

10. Korulikin Yu.D. (2001) Chemical composition of certain Sedum species of Kazakhstan, Chem. Nat. Prods., 37, 219-223.

11. Odontuya G. (2010) Application possibilities of Mongolian medicinal plants, Proc. The first International Forum for Mongolia Development, MIU, Ulaanbaatar, 44-51.

12. Odontuya G. (2015) Chemical constituents and biological activity of Myricaria alopecuroides Schrenk.
Proc. Conference "Meeting of Asia and Pacific Nation network and International Conference of Woman in Science, Technology, Engineering and Mathematics". Ulaanbaatar, 216-223.

13. Odontuya G., Choi YH., Ryu ShY., Kim YS., (2011) Anti-oxidative and antibacterial constituents from Sedum hybridum L. Nat.Prod.Sci., 17(4), 279-284.

14. Singleton V.L., Rossi J.A. (1965) Colorimetry of total phenolics with phosphomolybdic-phosphotungstic acid reagents. Am. J. Enol Vitic., 16, 144-153.

15. Maurya S., Singh D. (2010) Quantitative analysis of total phenolic content in Adhatoda vasica nees extracts. Inter. Jour. of Pharm Tech. Res., 2(4), 2403-2406.

16. Smirnov L.P., Pervikh L.N. (1998) Quantitative determination of total flavonoids in flowers of Helichrisum arenarium. Chem. Pharm. Jour., 6, 35-38.

17. Christ B., Muller K.H. (1960) Zur serienmaessigen Bestimmung des Gehaltes a Flavonol-Derivaten in Drogen. Arch. Pharm, 293, 1033-1042. (in german)

18. Determination of tannins in herbal drugs in: European Pharmacopeia 5.0, 221.

19. Mensor L.L., Menezes F.S., Leitao G.G., Reis A.S., Santos T.C., et al. (2001) Screening of Brazilian plant extracts for antioxidant activity by use of DPPH free radical method. Phytother. Res., 15, 127-130.

20. Ellman G.L., Courtney K.D., Andres V., Feater-Stone R.M. (1961) Anew and rapid colorimetric determination of acetylcholinesterase activity. Biochem. Pharmacol., 7, 88-95.

21. Kobayashi K., Takahashi T., Takano F., Fushiya S., Batkhuu J., et al. (2000) Survey of influence of Mongolian plants on lipase activity mouse plasma and gastrointestinal tube. Nat. Med., 58(5), 204-208.

22. Markham K.R, Ternai B., Stanley R., Geiger H., Mabry T.J. (1978) Carbon-13 NMR studies of flavonoids - III, Tetrahedron, 34, 1389-1397.

23. Harborne J.B. (1994) The flavonoids, Advances in research since 1986. Chapman and Hall: London; 448-496.

24. Sandongi Ch., Osakabe N., Natsume M., Takizawa T., Gomi Sh., et al. (1998) Antioxidative polyphenols isolated from Theobroma cacao. J. Agric. Food Chem., 46, 454-457.

25. Bouktaib M., Atmani A., Ronaldo Ch. (2002) Regio- and stereoselective synthesis of the major metabolite quercetin, quercetin-3-O- $\beta$-D-glucuronide, Tetrahedron Lett., 43, 6263-6266.

26. Gerhardt G., Sinnwell V., Kraus Lj. (1989) Isolierung von quercetin-3-glucuronid aus heidelbeer- und Rauschbeerblaettern durch DCCC, Planta Med., 55, 200-201.

27. Shigematsu N., Kouno I., Kawano N., (1982) Quercetin 3-(6"-caffeoylgalactoside) from Hydrocotyle sibthorpioides. Phytochem., 21(8), 2156-2158.

28. Kazuma K., Noda N., Suzuki M. (2003) Malonylated flavonol glycosides from the petals of Clitoria ternatea. Phytochem., 62, 229-237.

29. Kim YK., Kim YS., Choi SU., Ryu ShY. (2004) Isolation of flavonol rhamnosides from Loranthus tanakae and cytotoxic effect of them on human tumor cell lines. Arch. Pharm. Res., 27(1), 44-47.

30. Nawwar M.A.M., Souleman A.M.A., Buddrus J., 
Linschied M. (1984) Flavonoids of the flowers of Tamarix nilotica. Phytochem., 23, 2347-2349.

31. Beninger C.W., Hosfield G.L. (1999) Flavonoid composition of three genotypes of dry bean (Phaseolus vulgaris) differing in seedcoat color. J. Amer. Soc. Hort. Sci., 124(5), 514-518.

32. Budzianowski J., Skrzypczak L., (1995) Phenylpropanoid esters from Lamium album flowers. Phytochem., 38(4), 997-1001.

33. Price K.R., Colquhoun I.J., Barnes K.A., Rhodes M.C. (1998) Composition and content of flavonol glycosides in green beans and their fate during processing, $J$. Agric. Food Chem., 46, 4898-4903.

34. Agrawal P.K., Rastogi R.D. (1981) Carbon ${ }^{13} \mathrm{NMR}$ spectroscopy of flavonoids. Heterocyc., 16(12), 21812236.

35. Yasukawa K., Ogawa H., Takido M. (1990) Two flavovonol glycosides from Lysimachia nummularia. Phytochem., 29(5), 1707-1708.

36. Harborne B., Mabry T.J. (1988) The flavonoids. Advances in research since 1980. Chapman and Hall: London.

37. Kurkin V,A., Zapesochnaya G.G., Shchavlinskii A.N. (1984) Flavonoids from aerial parts of Rhodiola rosea, Khim. Prir. Soed., 5, 657-658.

38. Tuong PT., Kang HJ., Na MK., Jin WY., Youn UJ., et al. (2007) Anti-oxidant constituents from Sedum takesimense. Phytochem., 68, 14, 2015-2022.

39. Itokawa H., Suto K., Takeya K. (1981) Studies on a novel $p$-coumaroyl glucoside of apigenin and on other flavonoids isolated from Patchouli (Labiatae). Chem. Pharm. Bull., 29(1), 254-256.

40. Hye M.A., Taher M.A., Ali M.Y., Ali M.U., Zaman Sh. (2009) Isolation of (+) catechin from Acacia cathehu (Cutch tree) by a convenient method, J. Sci. Res., 1(2), 300-305.

41. Sakar M.K., Petereit F., Nahrstedt A. (1993) Two phrologlucinol glucosides, flavan gallates and flavonol glycosides from Sedum sediforme flowers. Phytochem., 33(1), 171-174.

42. Sato Yo., Oketani H., Singyouchi K., Ohtsubo T., Kihara M., Shibata H., Higuti T. (1997) Extraction and purification of effective antimicrobial constituents of Terminalia chebula Rets. against meticillin resistant Staphylococcus aureus. Biol. Pharm. Bull., 20(4), 401-404.

43. Chen X-M., Yoshida T., Hatano Ts., Fukushima M., Okuda T. (1987) Galloylarbutin and other polyphenols from Bergenia purpurascens. Phytochem., 26(2), 515-517.

44. Feldman K.S., Sahasrabudhe K. (1999) Ellagitannin chemistry: Syntheses of tellimagrandin II and a dehydrodigalloyl ether-containing dimeric gallotannin analogue of coriarin A". J. Org. Chem., 64, 209-216.

45. Cui Ch-B., Tezuka Ya., Kikuchi T., Nakano H., Tamaoki T., et al. (1990) Constituents of a Fern, Davallia mariesii Moore. I. Isolation and structures of davallialactone and a new flavanone glucuronide. Chem. Pharm. Bull., 38(12), 3218-3225.
46. Shen Ya-Ch., Lin Sh L. (1996) New secoiridoid glucosides from Jasminum lanceolarium. Planta Med., 62, 515-518.

47. Seebacher W., Simic N., Weis R., Saf R., Kunert O. (2003) Spectral assignments and reference data, Magn. Reson. Chem., 41, 636-638.

48. Ahmad F.,Ali M., Alam P.,(2010)New phytoconstituents from the stem bark of Tinospora cordifolia Miers. Nat. Prod. Res., 24(10), 926-934.

49. Usuki S., Ariga T., Dasgupta S., Kasama T., Morikawa K., et al. (2008) Structural analysis of novel bioactive acylated steryl glucosides in pre-germinated brown rice bran, J. of Lipid Res., 49, 2188-2196.

50. Knothe G., Kenar J.A. (2004) Determination of the fatty acid profile by ${ }^{1} \mathrm{H}$ NMR spectroscopy. Eur. J. Lipid Sci. Technol., 106, 88-96.

51. Halliwell B. (1997) Antioxidants and human diseases: a general introduction. Nutr. Rev., 5, 544-552.

52. Rice-Evans C.A., Miller N.J., Paganga G. (1996) Structure-antioxidant activity relationships of flavonoids and phenolic acids. Free Rad. Biol. and Med., 20(7), 933-956.

53. Pietta P-G. (2000) Flavonoids as antioxidants. J. Nat. Prod., 63, 1035-1042.

54. Sroka Z. (2005)Antioxidative and antiradical properties of plant phenolics. Z. Naturforsch., 60, 833-843.

55. Orhan I., Kartal M., Tosun F., Sener B. (2007) Screening of various phenolic acids and flavonoid derivatives for their anticholinesterase potential. $Z$. Naturforsch., 62c, 829-832.

56. Uriarte-Pueyo I., Calvo M.I. (2011) Flavonoids as acetylcholinesterase inhibitors. Curr. Med. Chem., 18, 5289-5302.

57. Nakai, M., Fukui, Y., Asami, S., Toyoda-Ono, Y., Iwashita, T., et al. (2005) Inhibitory effects of oolong tea polyphenols on pancreatic lipase in vitro. J. Agric. Food Chem., 53, 4593-4598.

58. Han, I.K., Takaku, T., Li, J., Kimura, Y., Okuda, H. (1999) Anti-obesity action of oolong tea. J. Obes. Relat. Metab. Disord., 23, 98-105.

59. Lin, JK., Lin-Shiau, SY. (2006) Mechanisms of hypolipidemic and anti-obesity effects of tea and tea polyphenols. Mol. Nutr. Food Res., 50, 211-217.

60. Zhao C., Li C., Liu S., Yang L. (2014) The galloyl catechins contributing to main antioxidant capacity of tea made from Camellia sinensis in China. Sci World J., 4, 1-11.

61. Okello E.J., Leylabi R., McDougall G.J. (2012) Inhibition of acetylcholinesterase by green and white tea and their simulated intestinal metabolites. Food Funct., 3, 651-661.

62. Nakai, M., Fukui, Y., Asami, S., Toyoda-Ono, Y., Iwashita, T., et al. (2005) Inhibitory effects of oolong tea polyphenols on pancreatic lipase in vitro. J. Agric. Food Chem., 53, 4593-4598. 